\title{
Is idiopathic hirsutism (IH) really idiopathic? mRNA expressions of skin steroidogenic enzymes in women with IH
}

\author{
Serpil Taheri ${ }^{1,7}$, Gokmen Zararsiz ${ }^{2,7}$, Sulbiye Karaburgu ${ }^{3}$, Murat Borlu ${ }^{4}$, \\ Mahmut Tuncay Ozgun ${ }^{5}$, Zuleyha Karaca ${ }^{3}$, Fatih Tanriverdi ${ }^{3}$, Munis Dundar ${ }^{6}$, \\ Fahrettin Kelestimur ${ }^{3}$ and Kursad Unluhizarci ${ }^{3}$ \\ Departments of ${ }^{1}$ Medical Biology, ${ }^{2}$ Statistics, ${ }^{3}$ Endocrinology, ${ }^{4}$ Dermatology, ${ }^{5}$ Obstetrics and Gynecology, \\ ${ }^{6}$ Genetics, Erciyes University Medical School, Kayseri 38039, Turkey and ${ }^{7}$ Betul-Ziya Eren Genome and Stem Cell \\ Center, Erciyes University, Kayseri, Turkey
}

\author{
Correspondence \\ should be addressed \\ to K Unluhizarci \\ Email \\ kursad@erciyes.edu.tr
}

\begin{abstract}
Objective: Hirsutism results from hyperandrogenemia and/or exaggerated androgen responsiveness. Among various causes of hirsutism, some patients do not exhibit androgen excess which is called idiopathic hirsutism (IH). The pathogenesis of IH could not so far be clearly established.

Design: To investigate the mRNA expression of aromatase enzyme and the other enzymes having functional roles in the steroidogenic pathway, in freshly obtained skin tissue from subumbilical skin and the arm of the patients with IH and healthy women.

Methods: Twenty-one women with IH and 15 healthy women were included in the study. We aimed to determine mRNA expressions of genes associated with local androgen synthesis and metabolism (CYP11A1, STS, CYP19A1, SRD5A1, SRD5A2, HSD3B1, AR, COMT, ESR1, ESR2, HSD3B2, CYP17A1, SULT2A1, SULT1E1, HSD17B2, IL6, TGFB1, TNFA) from skin biopsy and blood samples of patients with IH and the data compared with healthy subjects.

Results: Patients with IH exhibit significantly lower interleukin 6 (IL6) mRNA expression and higher steroid sulphatase (STS) and hydroxysteroid (17beta) dehydrogenase 2 (HSD17B2), gene mRNA expression, respectively, in the subumbilical region skin biopsies. Similarly, patients with IH exhibit significantly lower IL6 mRNA expression and higher STS and HSD17B2 gene mRNA expression, respectively, in the arm skin compared to healthy women's subumbilical region.

Conclusions: In both arm and subumbilical skin biopsy of patients with IH, we observed an up-regulation of HSD17B2 and STS, decreased IL6 mRNA expression, probably determining an increase in the local amount of active androgens, which could then be used as substrate for other androgen metabolic routes.
\end{abstract}

\section{Introduction}

Hirsutism, which is characterized by excessive growth of terminal hair in a male pattern, is a common clinical condition in women. Hirsutism may result from various causes including polycystic ovary syndrome (PCOS), nonclassical congenital adrenal hyperplasia, adrenal or ovarian tumors or it may be idiopathic $(1,2)$. Idiopathic hirsutism (IH) is currently defined as hirsutism associated with normal ovulatory function and normal serum androgen levels (3). The prevalence of IH varies in different populations $(4,5,6)$. The pathogenesis of IH is not clear; increased peripheral $5-\alpha$ reductase activity (7) and androgen receptor $(\mathrm{AR})$ gene polymorphisms $(8,9)$ have been postulated to explain the pathogenesis of this disorder.

Previously we have shown that, although within normal limits, patients with $\mathrm{IH}$ have relatively higher serum androgen levels in comparison to healthy subjects.

Published by Bioscientifica Ltd. 
Accordingly, estradiol/testosterone ratio, which is a function of aromatase activity, was also found to be lower in patients with IH (10). On the other hand, human skin possesses all the enzymes necessary for androgen synthesis and catabolism indicating that it is an independent peripheral endocrine organ. Thus, in the present study we aimed to investigate the mRNA expression of aromatase enzyme and the other enzymes having functional roles in the steroidogenic pathway, in freshly obtained skin tissue from subumbilical skin and the arm.

\section{Subjects and methods}

Twenty-one women with IH seen consecutively in the Department of Endocrinology of Erciyes University and 15 control subjects were included in the study. The diagnosis of $\mathrm{IH}$ was based on the presence of hirsutism (modified Ferriman-Gallwey score >8) (11), regular ovulatory menstrual cycles (luteal phase serum progesterone level higher than $4 \mathrm{ng} / \mathrm{ml}$ ), and a normal serum androgen profile including testosterone, androstenedione and DHEAS. Hormonal evaluations were performed in the follicular phase of menstrual cycles, and an additional blood sample for serum progesterone level was obtained for the confirmation of ovulation in luteal phase.

Normal androgen levels were defined according to the reference values of the commercial assays. Thyroid dysfunction, hyperprolactinemia, nonclassical congenital adrenal hyperplasia, PCOS, adrenal/ovarian tumors were excluded with appropriate tests and imaging techniques. The purpose of the study was explained both to the patients and the control subjects, and informed consent was obtained before beginning the study. The study was approved by the local Ethics Committee.

Skin biopsy samples using $4 \mathrm{~mm}$ punch biopsies were taken under local anesthesia from the midline subumbilical area of the patients. Intact anagen hair follicles were isolated according to procedures previously described (12). Additionally, the same amount of sample was also obtained from the upper arm without hair.

Control subjects were recruited among patients admitted to the Obstetrics and Gynecology Department of Erciyes University for benign conditions such as tubal ligation. None of the control subjects had ovarian dysfunction, hirsutism or hyperandrogenemia. The same amount of tissue from the subumbilical area was obtained during the operation. For ethical reasons, only subumbilical region skin tissue was obtained in the control subjects. Skin biopsies were immediately taken into RNA later solution.

\section{Assay}

Testosterone (DIAsource Immunoassays, Louvain-laNevue, Belgium), DHEAS (Immunotech, Marseille, France), androstenedione (DSL-3800, Diagnostic System Laboratories, Inc., Texas, U Costa Mesa, CA, USA) were measured by RIA method. Serum SHBG (Immunotech IM3532, Prague, Czech Republic) was measured by IRMA. Serum estradiol level (ACS: 180, Bayer) was measured with a chemiluminescence enzyme immunoassay system. The free androgen index (FAI) was calculated using the following formula: testosterone $(\mathrm{nmol} / \mathrm{l}) /$ SHBG $(\mathrm{nmol} / \mathrm{l}) \times 100$.

Cytochrome $\mathrm{P} 450$, family 11 , subfamily A, polypeptide 1 (CYP11A1), steroid sulphatase (microsomal), isozyme $S$ (STS), cytochrome P450, family 19 , subfamily A, polypeptide 1, aromatase (CYP19A1), steroid 5alpha-reductase 1 (SRD5A1), steroid 5alpha reductase 2 (SRD5A2), 3beta hydroxysteroid dehydrogenase/delta(5) delta(4) isomerase type 1 (HSD3B1), 3beta-hydroxysteroid dehydrogenase/ delta(5) delta(4) isomerase type 2 (HSD3B2), AR, catechol$O$-methyltransferase (COMT), estrogen receptor 1 (ESR1), estrogen receptor 2 (ESR2), cytochrome P450, family 17, subfamily A, polypeptide 1 (CYP17A1), sulfotransferase family, cytosolic, 2A, DHEA preferring, member 1 (SULT2A1), sulfotransferase family 1E, estrogen-preferring, member 1 (SULT1E1), hydroxysteroid (17beta) dehydrogenase 2 (HSD17B2), interleukin 6 (IL6), transforming growth factor beta 1 (TGFß1), tumor necrosis factor alpha (TNFA) mRNA expressions from skin biopsy and blood samples of patients and control subjects were determined.

\section{RNA extraction, cDNA synthesis and quantitative PCR}

Total RNA was isolated from skin biopsy and peripheral blood mononuclear cells (PBMC) of patients and controls using the TRIZOL (Roche). Concentration and purity of RNA for each sample were confirmed using Nanodrop1000 (Thermo Scientific, San Jose, CA, USA). A total of $200 \mathrm{ng}$ RNA was used for cDNA synthesis in a $10 \mathrm{ml}$ reaction mixture with random hexamers using the SuperScript III First-Strand Synthesis SuperMix (Catalog number: 11752250 ABI, Life Technologies). The following thermal protocol was used: $10 \mathrm{~min}$ at $25^{\circ} \mathrm{C}, 120 \mathrm{~min}$ at $37^{\circ} \mathrm{C}$, 5 min at $85^{\circ} \mathrm{C} ; 4^{\circ} \mathrm{C}$ hold. cDNA was preamplified using TaqMan Pre-Amp Master Mix (Applied Biosystems, PN 4361128 ) with all the 18 pairs of gene specific primers, and $1.25 \mu \mathrm{l}$ of each cDNA sample was combined with $2.5 \mu \mathrm{l}$ of $2 \times$ TaqMan Pre-Amp Master Mix in wells of a 96-well PCR plate. The PCR cycle conditions were $95^{\circ} \mathrm{C}$ for $10 \mathrm{~min}$, followed by 14 cycles $\left(15 \mathrm{~s}\right.$ at $95^{\circ} \mathrm{C}$ and $4 \mathrm{~min}$ at $60^{\circ} \mathrm{C}$ ). 
Samples were treated with Exonuclease I (Thermo Scientific) to remove unconjugated primers by adding $2 \mu \mathrm{l}$ $(4 \mathrm{U} / \mu \mathrm{l})$. The PCR plate was moved to a thermal cycler (SensoQuest GmbH, Göttingen, Germany). The PCR cycle conditions were $30 \mathrm{~min}$ at $37^{\circ} \mathrm{C} ; 15 \mathrm{~min}$ at $80^{\circ} \mathrm{C} ; 4^{\circ} \mathrm{C}$ hold. All samples were diluted ten times in TE buffer ( $\mathrm{pH} 8$ ) (Life Technologies). Working of instruments, handling and processing of the IFC controller were performed using standardized protocol for gene expression analysis provided by Fluidigm. Samples were prepared for loading on a 96:96 Dynamic array IFC by combining $2.25 \mu$ l of each preamplified cDNA sample with $2.5 \mu 12 \times$ SsoFast EvaGreen Supermix with $0.25 \mu \mathrm{l} 20 \times$ DNA binding dye loading reagent (Fluidigm) and low ROX (Bio-Rad). A total of $5 \mu$ l of each preamplified cDNA sample and $5 \mu$ l of each DeltaGene assay were dispensed into their parallel inlets on the Dynamic array and samples were subjected to RT-qPCR using the following thermal cycling protocol: $40 \mathrm{~min}$ at $70^{\circ} \mathrm{C}$; $30 \mathrm{~s}$ at $60{ }^{\circ} \mathrm{C} ; 1 \mathrm{~min}$ at $95^{\circ} \mathrm{C} ; 35$ cycles $\left(96^{\circ} \mathrm{C}, 5 \mathrm{~s} ; 60^{\circ} \mathrm{C}, 20 \mathrm{~s}\right)$ and melting curve using a ramp from $60^{\circ} \mathrm{C}$ to $95^{\circ} \mathrm{C}$ at $1{ }^{\circ} \mathrm{C} / 3 \mathrm{~s}$.

\section{Statistical analysis}

Data was collected with Fluidigm Real-Time PCR analysis software using linear baseline correction method and auto global Cq threshold method. System given Cq values of 999, also Cq values larger than 23 were removed, since these readings were unreliable. Missing values were imputed using the median LOD Cq values calculated across all arrays. GeNORM was used to evaluate the expression stability of genes, and $\beta$-actin was used to normalize the qPCR data as an internal control (13). Normalizations of data were carried out using the comparative Cq method (14).
For the comparison of demographic and hormonal values of the patients and the control subjects, MannWhitney $U$ test was used. Histogram and q-q values were examined and Shapiro-Wilk's test was performed to assess the data normality. Levene test was used to test variance homogeneity. To compare the differences of demographic and basal hormone values between patient and control subjects, either an independent samples t-test or MannWhitney $U$ tests were applied. Covariance analysis were applied to compare the demographic and basal hormone values adjusted to BMI. To compare the mRNA expressions among groups, linear models for microarray and RNA-Seq data (limma) method was applied. Pearson correlation coefficients were calculated to identify the relationship among mRNA expressions. All $P$ values are adjusted using the Benjamini-Hochberg false discovery rate correction to account for multiple testing. Analyses were performed using Rcmdr (15) and limma (16) packages of R 3.1.1 software (URL http://www.R-project.org/). $P$ and adjusted $P$ values $<5 \%$ were considered as statistically significant.

\section{Results}

Patients and control subjects did not differ in mean age while control subjects were slightly more obese than the patient group. As expected, modified Ferriman-Gallwey score was significantly $(P<0.001)$ higher in the patient group. By definiton, all the patients and control women had normal serum androgen levels. However, patients with IH had significantly higher serum testosterone and DHEAS levels than the control subjects. The ratio of estradiol to testosterone was found to be significantly lower in the patient group as compared to healthy women $(P<0.05)$. The whole data is presented in Table 1 .

Table 1 Demographic and basal hormone values of the patients and control subjects. Values are expressed as mean \pm s.D. or median (1st to 3rd quartiles).

\begin{tabular}{lcc}
\hline Variables & & Normal value \\
\cline { 1 - 1 } Age (years) & NA \\
BMl $\left(\mathrm{kg} / \mathrm{m}^{2}\right)$ & $20-24.9$ \\
Modified FGS & $<8$ \\
DHEAS $(\mathrm{ng} / \mathrm{ml})$ & $1330-4410$ \\
Testosterone $(\mathrm{ng} / \mathrm{dl})$ & $6-82$ \\
Androstenedione $(\mathrm{ng} / \mathrm{ml})$ & $0.3-3.1$ \\
Estradiol $(\mathrm{pg} / \mathrm{ml})$ & $19-246$ \\
Estradiol/Testosterone & $\mathrm{NA}$ \\
SHBG $(\mathrm{nmol} / \mathrm{l})$ & & $\mathrm{NA}$ \\
FAl & & $\mathrm{N}$ \\
\hline
\end{tabular}

\begin{tabular}{c}
\hline Patient \\
\hline $26.55 \pm 7.67$ \\
$24.29 \pm 4.33$ \\
$13.00(10.00-14.00)$ \\
$2219.05 \pm 757.54$ \\
$53.00(42.00-64.00)$ \\
$1.45(0.975-1.825)$ \\
$46.00(38.00-64.00)$ \\
$0.98(0.70-1.14)$ \\
$33.00(23.50-62.00)$ \\
$4.62(3.44-7.70)$ \\
\hline
\end{tabular}

\begin{tabular}{c}
\hline Control \\
\hline $30.47 \pm 7.59$ \\
$27.20 \pm 3.76$ \\
$3.00(2.00-4.00)$ \\
$1553.73 \pm 729.80$ \\
$32.00(20.00-41.00)$ \\
$1.75(1.35-2.1)$ \\
$67.00(32.00-94.00)$ \\
$2.44(1.55-3.35)$ \\
$54.50(43.00-71.00)$ \\
$1.54(1.21-2.27)$ \\
\hline
\end{tabular}

$\begin{array}{r}\hline \boldsymbol{P} \text { value } \\ \hline 0.143 \\ 0.043 \\ <0.001 \\ 0.013 \\ <0.001 \\ 0.192 \\ 0.279 \\ 0.005 \\ 0.097 \\ <0.001 \\ \hline\end{array}$

\begin{tabular}{c}
\hline BMI adjusted $\boldsymbol{P}$ value \\
\hline 0.369 \\
NA \\
$<0.001$ \\
0.039 \\
0.007 \\
0.470 \\
0.117 \\
0.030 \\
0.008 \\
0.007
\end{tabular}

FGS, Ferriman-Gallwey score; FAI, free androgen index; NA, not applicable. ${ }^{a}$ Adjusted by BMI. 
In comparison to healthy subjects, patients with $\mathrm{IH}$ exhibited 5.4-fold lower IL6 mRNA expression and 2.2and 2.3-fold higher STS and HSD17B2 gene mRNA expression, respectively, in the subumbilical region skin biopsies. Similarly, patients with IH exhibited 4.8-fold lower IL6 mRNA expression and two- and 2.8-fold higher STS and HSD17B2 gene mRNA expression, respectively, in the arm skin compared to healthy women's subumbilical region $(P<0.001)$. There was no significant difference in any gene expression between the arm and subumbilical skin biopsies of the patient group. In addition, there were no significant differences in any gene expression in PBMC of patients and healthy women. All studied genes represented in the androgen biosynthesis pathway are shown in Fig. 1. The whole statistical data is presented in Fig. 2 and Table 2. In addition, Heat map graphics which shows the whole data with different colors associated with the level of

\section{Discussion}

Hirsutism results from hyperandrogenemia and/or exaggerated androgen responsiveness. Among various causes of hirsutism, some patients do not exhibit androgen excess which is called IH. The pathogenesis of IH could not be established clearly so far. Currently, the pathophysiology of IH is presumed to be a primary increase in skin $5 \alpha$ reductase activity and possibly an alteration in AR function (3).

We have previously shown (10) that patients with IH had significantly higher testosterone levels and lower estradiol levels than healthy women which suggested a possible role of increased local androgen synthesis in the pathogenesis of IH. Although we did not use mass spectrophotometry for the measurement of serum androgens, which can be considered as a limitation of the study, the present data confirmed our previous findings. An association of a possible local overproduction of active androgens and skin disorders such as acne and

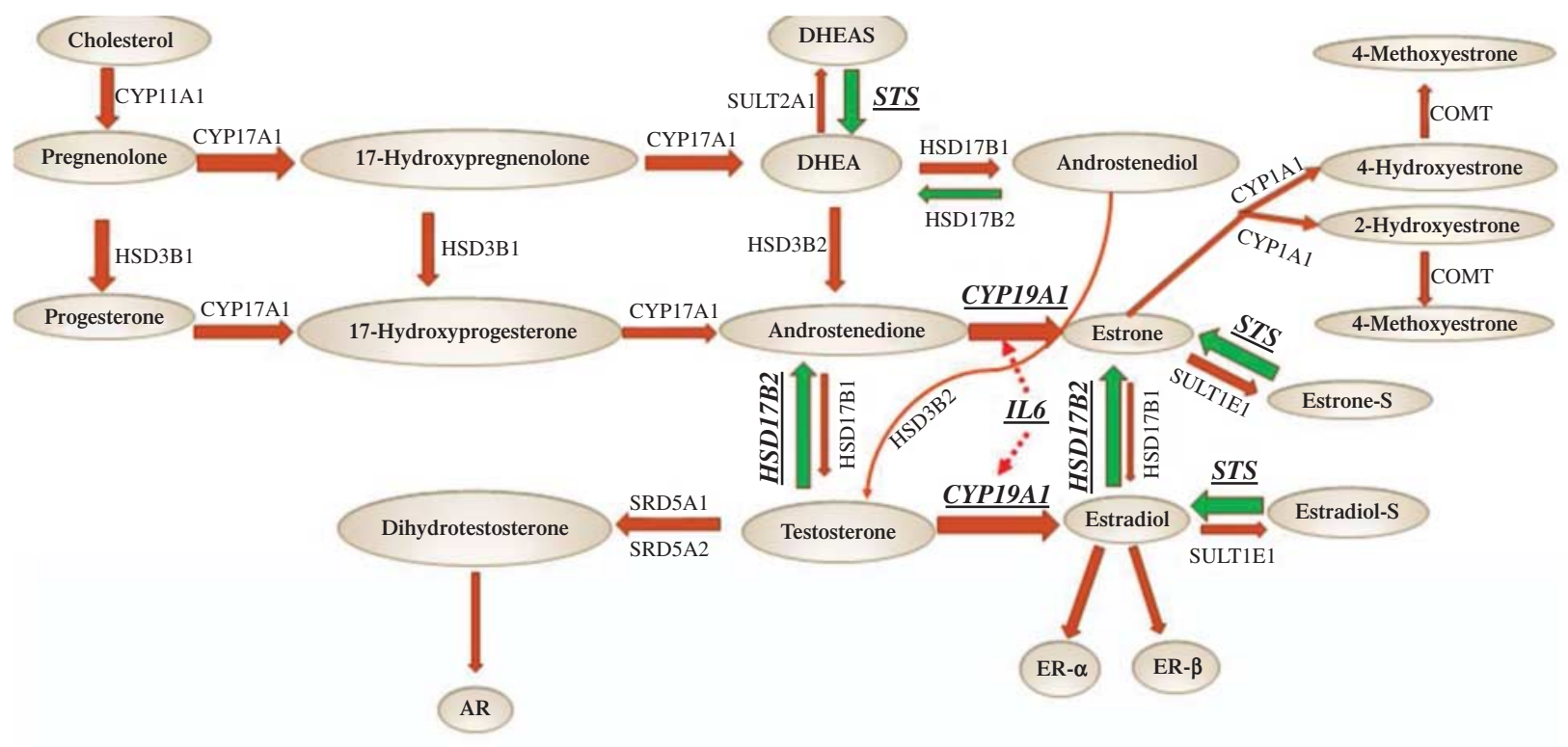

\footnotetext{
$\Rightarrow$ High mRNA expression according to control tissue $(P<0.001)$

$m=n=\Rightarrow$ Low mRNA expression according to control tissue $(P<0.001)$

There isn't any difference between patients and control tissue $(P>0.05)$
}

\section{Figure 1}

A schematic presentation of the steroid biosynthesis with altered mRNA expressions of the enzymes involved in the androgen biosynthesis. 


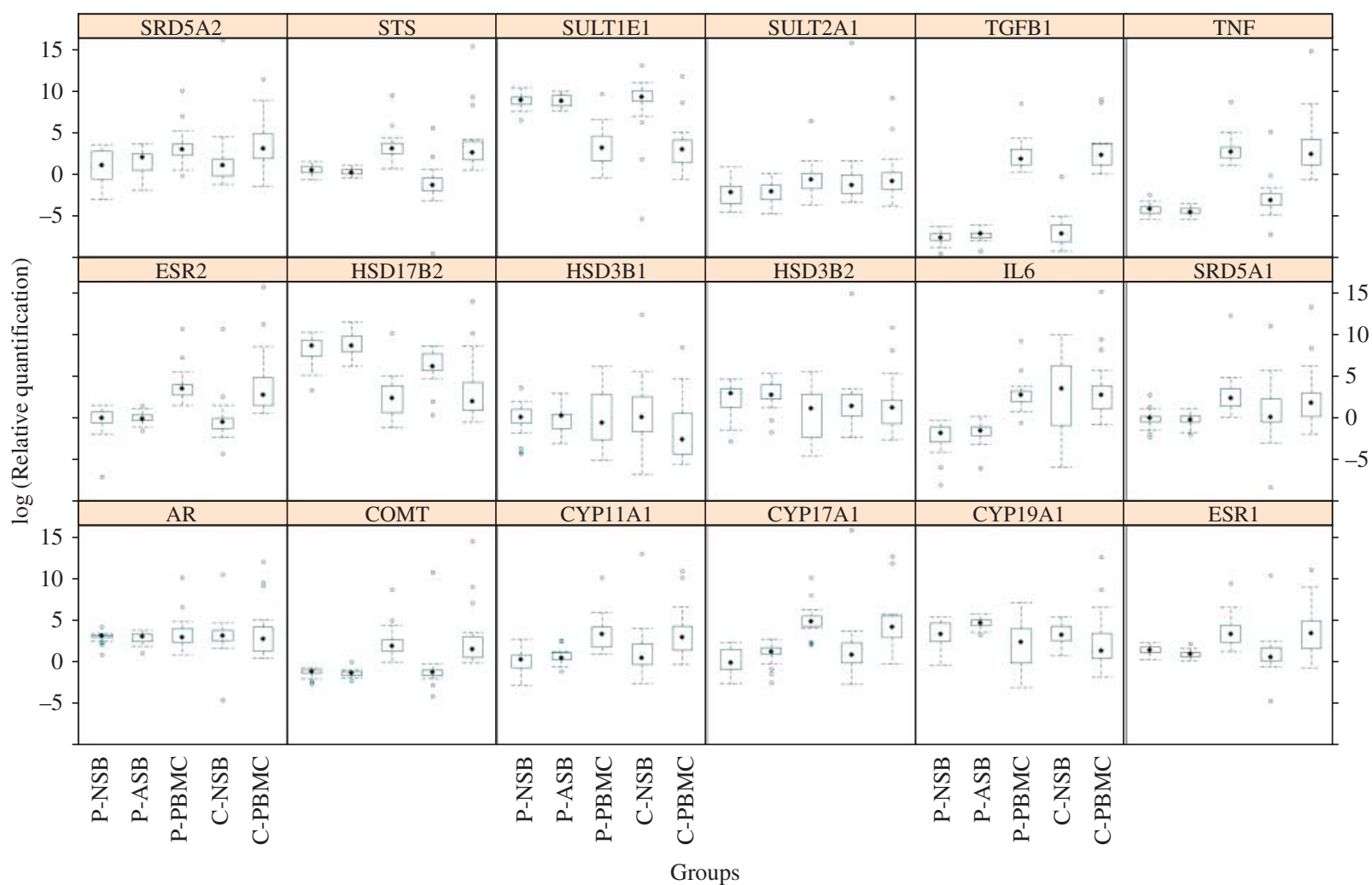

\section{Figure 2}

Boxplots displaying the distribution of relative quantification of gene expressions associated with androgen synthesis and metabolism in logarithmic scale. STS, HSD17B2 gene expressions were determined significantly up-regulated, IL6 gene expression was determined significantly down-regulated in

androgenetic alopecia (AGA) in males has been suggested by several studies (17). Thus, in this study, we aimed to investigate the gene expression of various enzymes responsible for the cutaneous androgen synthesis and metabolism in patients with IH. At least to our knowledge, there is no study investigating the mRNA expression of enzymes having a role in locally produced androgens and their precursors in freshly obtained hair follicles in patients with IH.

The cutaneous expression of steroidogenic acute regulatory protein, cytochrome $\mathrm{P} 450$ cholesterol sidechain cleavage (P450scc) and cytochrome P450 17-alpha hydroxylase (P450c17) have been demonstrated previously which suggest that the cutaneously derived cholesterol could be further used as a substrate for de novo steroid hormone synthesis in human epidermis and the sebaceous gland (18). Moreover, in peripheral organs, such as the skin, the potent tissue androgen testosterone patients according to controls $(P<0.001)$. P-USB, patient's subumbilical region skin biopsy; C-USB, control's subumbilical region skin biopsy; P-PBMC, patient's peripheral blood mononuclear cells; C-PBMC, control's peripheral blood mononuclear cells; P-ASB, patient's arm skin biopsy.

results from the conversion of circulating DHEAS, a weak but most abundant androgen, through the serial action of

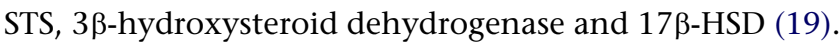
The type 2 enzyme of $17 \beta$-HSD inactivates both estradiol and testosterone to estrone and androstenedione, respectively (20). In our study, we have shown that in comparison to healthy subjects, women with IH demonstrated higher expression of STS and HSD17B2 mRNA both in the subumbilical region and arm skin, suggesting they contribute to local androgen metabolism.

As in AGA, abnormal serum concentrations of testosterone or $5 \alpha$ DHT are not a prerequisite for the development of androgenic disorders (21). In such diseases, including $\mathrm{IH}$, locally produced androgens seem to have an important role. DHEAS is an important endocrine factor providing local androgen synthesis via STS even in the presence of normal DHEAS levels. STS is present in almost all mammalian tissues (22) and DHEAS 
Table 2 The distribution of gene expression levels between idiopathic hirsutism and control groups. Values are expressed as median (1st/3rd quartiles).

\begin{tabular}{|c|c|}
\hline Gene & P-PBMC \\
\hline$A R$ & $3.03(2.46 / 4.04)$ \\
\hline HSD3B1 & $-0.57(-2.61 / 2.79)$ \\
\hline TGFB1 & $1.68(1.08 / 2.81)$ \\
\hline COMT & $1.98(1.38 / 2.75)$ \\
\hline HSD3B2 & $1.07(-2.36 / 2.82)$ \\
\hline$T N F$ & $2.52(1.93 / 3.13)$ \\
\hline IL6 & $2.7(2.01 / 3.17)$ \\
\hline CYP11A1 & $3.41(1.84 / 4.22)$ \\
\hline CYP17A1 & $4.93(4.31 / 5.58)$ \\
\hline SRD5A1 & $2.37(1.36 / 3.49)$ \\
\hline CYP19A1 & $2.42(-0.01 / 4.05)$ \\
\hline SRD5A2 & $2.84(2.14 / 3.56)$ \\
\hline ESR1 & $3.37(2.41 / 4.46)$ \\
\hline STS & $2.95(2.33 / 3.60)$ \\
\hline ESR2 & $3.47(2.74 / 3.99)$ \\
\hline SULT1E1 & $3.07(1.48 / 4.47)$ \\
\hline HSD17B2 & $2.32(0.62 / 3.89)$ \\
\hline SULT2A1 & $-0.82(-1.79 / 0.00)$ \\
\hline
\end{tabular}

\begin{tabular}{c}
\hline C-PBMC \\
\hline $2.82(1.35 / 4.27)$ \\
$-2.58(-4.29 / 0.49)$ \\
$2.16(1.00 / 3.56)$ \\
$1.61(0.63 / 3.11)$ \\
$1.16(-0.75 / 2.20)$ \\
$2.29(1.01 / 4.10)$ \\
$2.70(1.07 / 3.88)$ \\
$3.03(1.44 / 4.34)$ \\
$4.26(3.00 / 5.59)$ \\
$1.77(0.14 / 3.04)$ \\
$1.36(0.48 / 3.46)$ \\
$2.96(1.81 / 4.71)$ \\
$3.45(1.62 / 5.01)$ \\
$2.44(1.56 / 3.84)$ \\
$2.69(1.50 / 4.84)$ \\
$2.87(1.36 / 3.98)$ \\
$2.00(0.96 / 4.22)$ \\
$-1.01(-1.91 / 0.03)$ \\
\hline
\end{tabular}

\begin{tabular}{c}
\hline P-ASB \\
\hline $3.11(2.56 / 3.36)$ \\
$0.28(-1.29 / 0.48)$ \\
$-7.29(-7.77 /-7.15)$ \\
$-1.32(-1.55 /-1.10)$ \\
$2.70(2.28 / 3.94)$ \\
$-4.69(-4.78 /-4.23)$ \\
$-1.57(-2.12 /-1.13)$ \\
$0.51(0.35 / 1.15)$ \\
$1.25(0.96 / 1.74)$ \\
$-0.22(-0.56 / 0.27)$ \\
$4.72(4.42 / 5.05)$ \\
$1.88(0.39 / 2.37)$ \\
$1.01(0.67 / 1.20)$ \\
$\mathbf{0 . 1 1}(-0.08 / 0.46)$ \\
$-0.16(-0.36 / 0.32)$ \\
$8.65(8.06 / 9.31)$ \\
$8.67(7.98 / 9.81)$ \\
$-2.18(-3.17 /-1.42)$ \\
\hline
\end{tabular}

\begin{tabular}{c} 
P-USB \\
\hline $3.15(2.95 / 3.31)$ \\
$0.05(-0.65 / 0.98)$ \\
$-7.70(-8.07 /-7.25)$ \\
$-1.13(-1.32 /-0.87)$ \\
$2.92(1.25 / 3.54)$ \\
$-4.29(-4.76 /-4.02)$ \\
$-1.88(-2.92 /-1.12)$ \\
$0.28(-0.63 / 0.85)$ \\
$-0.10(-0.87 / 1.56)$ \\
$-0.04(-0.51 / 0.17)$ \\
$3.41(2.53 / 4.72)$ \\
$0.92(-0.69 / 2.62)$ \\
$1.44(1.14 / 1.88)$ \\
$0.37(0.09 / 0.87)$ \\
$-0.01(-0.57 / 0.71)$ \\
$8.80(8.29 / 9.14)$ \\
$\mathbf{8 . 6 7}(7.42 / 9.29)$ \\
$-2.28(-3.61 /-1.51)$ \\
\hline
\end{tabular}

\begin{tabular}{c}
\hline C-USB \\
\hline $3.18(2.59 / 3.86)$ \\
$0.03(-1.66 / 2.51)$ \\
$-7.26(-8.23 /-6.26)$ \\
$-1.24(-1.55 /-0.91)$ \\
$1.44(0.21 / 2.80)$ \\
$-3.26(-3.86 /-2.44)$ \\
$3.46(-0.91 / 6.25)$ \\
$0.51(-0.22 / 2.21)$ \\
$0.87(-0.01 / 2.31)$ \\
$0.01(-0.50 / 2.26)$ \\
$3.30(2.57 / 4.35)$ \\
$0.98(-0.31 / 1.74)$ \\
$0.59(0.11 / 1.79)$ \\
$-1.43(-2.07 /-0.60)$ \\
$-0.50(-1.26 /-0.01)$ \\
$9.16(8.62 / 9.89)$ \\
$6.15(5.68 / 7.68)$ \\
$-1.42(-2.44 /-0.23)$ \\
\hline
\end{tabular}

P-USB, patient's subumblical region skin biopsy; C-USB, control's subumblical region skin biopsy; P-PBMC, patient's peripheral blood mononuclear cells; C-PBMC, control's peripheral blood mononuclear cells; P-ASB, patient's arm skin biopsy. Statistically significant genes are shown in bold.

is a substrate for this microsomal enzyme. Hoffmann et al. (23) performed immunostaining for STS on human scalp biopsies as well as analysis of STS enzyme activity in occipital hair follicles. Using both methods, STS was primarily detected in the dermal papilla and the dermal papilla was able to utilize DHEAS to produce $5 \alpha$ DHT.
Furthermore, a potent STS inhibitor efficiently blocked the activity of enzyme even in very low concentrations (23).

mRNA expression level may reflect the response at the protein level or at the level of active enzyme that there is a static correlation between levels of mRNA, protein, and active enzyme $(24,25)$. On the other hand, studies showed

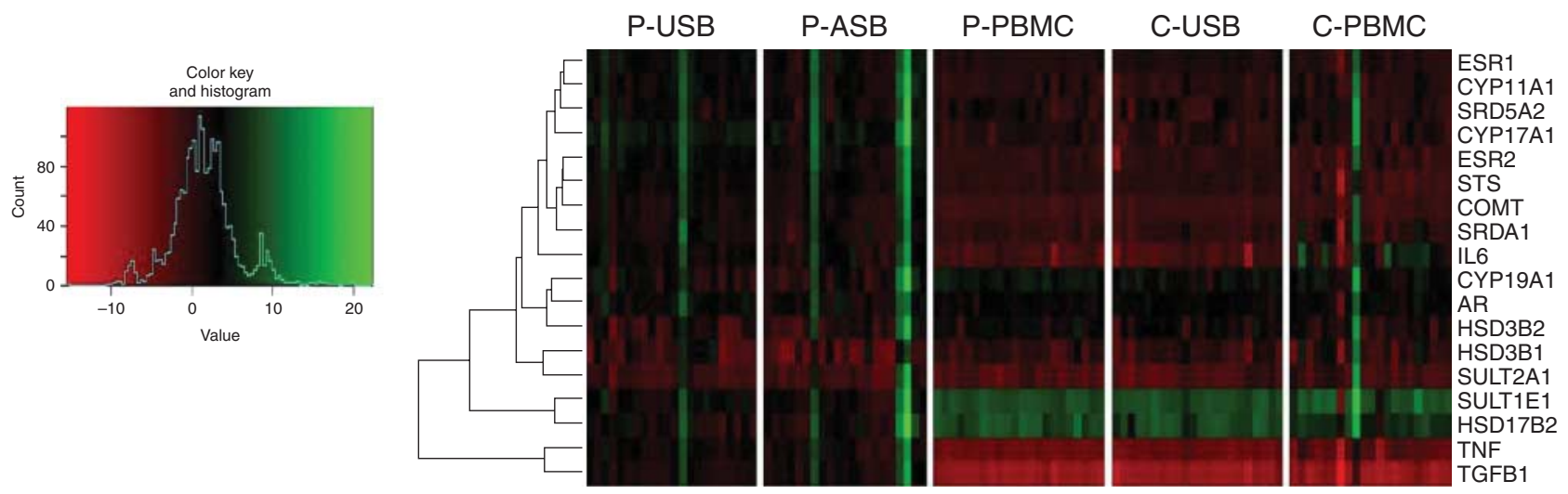

\section{Figure 3}

Heatmap plot displaying the expression values of genes associated with androgen synthesis and metabolism in each group. Patterns of gene expression profiles for the 18 differentially expressed genes. STS, HSD17B2 gene expressions were determined significantly up-regulated, IL6 gene expression was determined significantly down-regulated in patients according to controls $(P<0.001)$. In the cluster figure, columns represent samples and rows represent genes (black, red and green correspond to unchanged, down-regulated, and up-regulated, respectively). P-USB, patient's subumbilical region skin biopsy; C-USB, control's subumbilical region skin biopsy; P-PBMC, patient's peripheral blood mononuclear cells; C-PBMC, control's peripheral blood mononuclear cells; P-ASB, patient's arm skin biopsy. 
some evidence for the existence of a disparity between the relative expression levels of mRNAs and their corresponding proteins. The transcription level is not always correlated with the enzyme activity as a result of posttransciptional and post-translational regulatory events $(26,27)$. Although we do not measure the STS enzyme activity, increased mRNA expression may be a clue for the tendency to local hyperandrogenemia in women with IH. Additionally, increased mRNA expression of STS also in the arm skin without hair suggests an overall increased expression in idiopathic hirsute patients (Figs 1 and 2). As in AGA, our study showed that in women with IH, STS gene expression is significantly higher irrespective of the body area than in healthy women.

We also found increased HSD17B2 gene expression which is another steroidogenic enzyme present in the pilosebaceous unit catalyzing both the formation of testosterone and estradiol (via reduction) and backconversion of these hormones to less active precursors (via oxidation). Oliveira et al. (28), found reduced gene expression of $H S D 17 B 2$ in the scalp of hirsute women with PCOS or IH probably determining an increase in the local amount of active androgens. In contrast, we have found increased gene expression of the same enzyme which may not be considered as conflicting results, since it is well known that hair follicles from different body sites have different responses to androgens and they have variations in intracellular androgen metabolism. In addition, Oliveira et al. (28) used reverse transcriptase PCR in their study for describing mRNA expression levels. We used real time PCR in our study for describing mRNA expression levels. Real time PCR method is more sensitive than reverse transcriptase PCR (29).

Increased HSD17B2 mRNA expression was associated with decreased testosterone levels in SZ95 immortalized sebocytes (30). While inactivation of testosterone via increased HSD17B2 lead to hypoandrogenic milieu, simultaneous effect of $H S D 17 B 2$ on estradiol inactivation may counteract this hypoandrogenic situation. Effect of HSD17B2 on inactivation of both testosterone and estradiol has been shown previously (31). Overall, our data suggest that patients with IH have increased HSD17B2 expression irrespective of the body area in comparison to healthy women and may have a regulatory role in the androgen metabolism of patients with IH.

In our study, we have shown that mRNA expression of IL6, which affects aromatase expression, is significantly lower in patients with IH than in healthy subjects in the skin biopsies (Figs 1 and 2). We can speculate that local synthesis of estrogen may be negatively affected by (indirect) effect of aromatase activity. The regulation of aromatase expression in human cells via alternatively used promoters, which can be activated or inhibited by various hormones, increases the complexity of estrogen biosynthesis in the human body (32).

In conclusion, our results suggest that IH is characterized by decreased estradiol/testosterone ratio. The increased gene expression of HSD17B2 and STS, decreased IL6 are not dependent on circulating levels of testosterone since those patients are not hyperandrogenic. In both, arm and umbilical skin biopsy of patients with $\mathrm{IH}$, we observed an up-regulation of HSD17B2 and STS, decreased IL6, probably determining an increase in the local amount of active androgens, which could then be used as a substrate for other androgen metabolic routes.

\section{Declaration of interest}

The authors declare that there is no conflict of interest that could be perceived as prejudicing the impartiality of the research reported.

\section{Funding}

The current study was supported by the Scientific Research Unit of the Erciyes University, under the project number TSA-12-4053.

\section{Author contribution statement}

F Kelestimur, K Unluhizarci, Z Karaca, F Tanriverdi and S Taheri conceived and designed the experiments and the main research hypothesis. M Borlu and M T Ozgun collected blood and skin biopsy material from patients and controls. M Dundar, S Karaburgu and S Taheri performed the experiments. G Zararsiz performed the statistical analysis and data representation. Z Karaca, F Tanriverdi analyzed the draft manuscript and corrected the style and proper contents of this paper. $\mathrm{K}$ Unluhizarci and $\mathrm{F}$ Kelestimur contributed and analyzed the clinical data of included cases. F Kelestimur, $\mathrm{K}$ Unluhizarci and S Taheri supervised all the steps of this work including the experiments. All the aforementioned authors fully contributed to the reading, writing, and approval of the final version of this manuscript.

\section{References}

1 Escobar Morealle HF, Carmina E, Dewailly D, Gambineri A, Kelestimur F, Moghetti P, Pugeat M, Qiao J, Wijeyaratne CN, Witchel SF et al. Epidemiology, diagnosis and management of hirsutism: a consensus statement by the Androgen Excess and Polycystic Ovary Syndrome Society. Human Reproduction Update 201218 146-170. (doi:10.1093/humupd/dmr042)

2 Azziz R, Sanchez LA, Knochenhauer ES, Moran C, Lazenby J, Stephens KC, Taylor K \& Boots LR. Androgen excess in women: experience with over 1000 consecutive patients. Journal of Clinical Endocrinology and Metabolism 200489 453-462. (doi:10.1210/ jc.2003-031122)

3 Azziz R, Carmina E \& Sawaya ME. Idiopathic hirsutism. Endocrine Reviews 200021 347-362. (doi:10.1210/edrv.21.4.0401) 
4 Carmina E. Prevalence of idiopathic hirsutism. European Journal of Endocrinology 1998139 421-423. (doi:10.1530/eje.0.1390421)

5 Azziz R, Waggoner WT, Ochoa T, Knochenhauer ES \& Boots LR. Idiopathic hirsutism: an uncommon cause of hirsutism in Alabama. Fertility and Sterility 199870 274-278. (doi:10.1016/S00150282(98)00141-1)

6 Unluhizarci K, Gokce C, Atmaca H, Bayram F \& Kelestimur F. A detailed investigation of hirsutism in a Turkish population: idiopathic hyperandrogenemia as a perplexing issue. Experimental and Clinical Endocrinology \& Diabetes 2004112 504-509. (doi:10.1055/s-2004-821307)

7 Serafini P \& Lobo RA. Increased $5 \alpha$-reductase activity in idiopathic hirsutism. Fertility and Sterility $1985 \mathbf{4 3}$ 74-78.

8 Sawaya ME \& Shalita AR. Androgen receptor polymorphisms (CAG repeat lengths) in androgenetic alopesia, hirsutism and acne. Journal of Cutaneous Medicine and Surgery 1998 39-15.

9 Legro RS, Shahbahrami B, Lobo RA \& Kovacs BW. Size polymorphisms of the androgen receptor among female Hispanics and correlations with androhenic characteristics. Obstetrics \& Gynecology 199483 701-706.

10 Unluhizarci K, Karababa Y, Bayram F \& Kelestimur F. The investigation of insulin resistance in patients with idiopathic hirsutism. Journal of Clinical Endocrinology and Metabolism 200489 2741-2744. (doi:10.1210/ jc.2003-031626)

11 Hatch R, Rosenfield RL, Kim MH \& Tredway D. Hirsutism: implications, etiology and management. American Journal of Obstetrics and Gynecology $1981140815-830$

12 Caglayan AO, Dundar M, Tanriverdi F, Baysal NA, Unluhizarci K, Ozkul Y, Borlu M, Batukan C \& Kelestimur F. Idiopathic hirsutism: local and peripheral expression of aromatase (CYP19A) and $5 \alpha$-reductase genes (SRD5A1 and SRD5A2). Fertility and Sterility 201196 479-482. (doi:10.1016/j.fertnstert.2011.05.040)

13 Vandesompele J, De Preter K, Pattyn F, Poppe B, Van Roy N, De Paepe A $\&$ Speleman F. Accurate normalization of real-time quantitative RT-PCR by geometric averaging of multiple internal control genes. Genome Biology 20023 1-12. (doi:10.1186/gb-2002-3-7-research0034)

14 Livak KJ \& Schmittgen TD. Analysis of relative gene expression data using real-time quantitative PCR and the 2(-Delta Delta C (T)) Method. Methods 200125 402-408. (doi:10.1006/meth.2001.1262)

15 Fox J. Getting started with the The R Commander: A Basic Statistics Graphical User Interface to R. Journal of Statistical Software 200514 1-42.

16 Smyth GK. Linear models and empirical Bayes methods for assessing differential expression in microarray experiments. Statistical Applications in Genetics and Molecular Biology 20043 Article 3. (doi:10.2202/1544-6115.1027)

17 Zouboulis CC \& Deqitz K. Androgen action on human skin - from basic research to clinical significance. Experimental Dermatology 200413 (Suppl 4) 5-10. (doi:10.1111/j.1600-0625.2004.00255.x)

18 Chen W, Thiboutot D \& Zouboulis CC. Cutaneous androgen metabolism: basic research and clinical perspectives. Journal of Investigative Dermatology 2002119 992-1007. (doi:10.1046/j.15231747.2002.00613.x)

19 Fritsch M, Orfanos CE \& Zouboulis CC. Sebocytes are the key regulators of androgen homeostasis in human skin. Journal of Investigative Dermatology 2001116 793-800. (doi:10.1046/j.1523-1747.2001.01312.x)
$20 \mathrm{Wu}$ L, Einstein M, Geissler WM, Chan HK, Elliston KO \& Andersson S. Expression cloning and characterization of human $17 \beta$-hydroxysteroid dehydrogenase type 2 , a microsomal enzyme possessing $20 \alpha$-hydroxysteroid dehydrogenase activity. Journal of Biological Chemistry 1993268 12964-12969.

21 Messenger AG. Androgen effects on hair growth. Dermatologic Therapy 19988 7-18.

22 Martel C, Melner MH, Gagne D, Simard J \& Labrie F. Widespread tissue distribution of steroid sulfatase, 3- $\beta$ hydroxy steroid dehydrogenase/

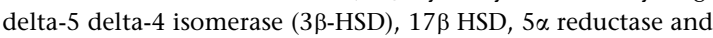
aromatase activities in the rhesus monkey. Molecular and Cellular Endocrinology 1994104 103-111. (doi:10.1016/0303-7207(94)90056-6)

23 Hoffmann R, Rot A, Niiyama S \& Billich A. Steroid sulfatase in the human hair follicle concentrates in the dermal papilla. Journal of Investigative Dermatology 2001117 1342-1348. (doi:10.1046/j.0022202x.2001.01547.x)

24 Chen J, Lipska BK, Halim N, Ma QD, Matsumoto M, Melhem S, Kolachana BS, Hyde TM, Herman MM, Apud J et al. Functional analysis of genetic variation in catechol-O-methyltransferase (COMT): effects on mRNA, protein, and enzyme activity in postmortem human brain. American Journal of Human Genetics 200475 807-821. (doi:10.1086/425589)

25 Hargrove JL \& Schmidt FH. The role of mRNA and protein stability in gene expression. FASEB Journal 19893 2360-2370.

26 Ohtsuki S, Schaefer O, Kawakami H, Inoue T, Liehner S, Saito A, Ishiguro N, Kishimoto W, Ludwig-Schwellinger E, Ebner T et al. Simultaneous absolute protein quantification of transporters, cytochromes P450, and UDP-glucuronosyltransferases as a novel approach for the characterization of individual human liver: comparison with mRNA levels and activities. Drug Metabolism and Disposition 201240 83-92. (doi:10.1124/dmd.111.042259)

27 Gen K, Okuzawa K, Kumakura N, Yamaguchi S \& Kagawa H. Correlation between messenger RNA expression of cytochrome $\mathrm{P} 450$ aromatase and its enzyme activity during oocyte development in the red seabream (Pagrus major). Biology of Reproduction 200165 1186-1194. (doi:10.1095/biolreprod65.4.1186)

28 Oliveira IO, Lhullier C, Brum IS \& Spritzer PM. Gene expression of type $217 \beta$ hydroxysteroid dehydrogenase in scalp hairs of hirsute women. Steroids 200368 641-649. (doi:10.1016/S0039-128X(03)00093-X)

29 Wong ML \& Medrano JF. Real-time PCR for mRNA quantitation. Biotechniques 200539 75-85. (doi:10.2144/05391RV01)

30 Inoue T, Miki Y, Kakuo S, Hachiya A, Kitahara T, Aiba S, Zouboulis CC \& Sasano H. Expression of steroidogenic enzymes in human sebaceous glands. Journal of Endocrinology 2014222 301-312. (doi:10.1530/ JOE-14-0323)

31 Puranen TJ, Kurkela RM, Lakkakorpi JT, Poutanen MH, Itäranta PV, Melis JP, Ghosh D, Vihko RK \& Vihko PT. Characterization of molecular and catalytic properties of intact and truncated human 17 $\beta$-hydroxysteroid dehydrogenase type 2 enzymes: intracellular localization of the wild-type enzyme in the endoplasmic reticulum. Endocrinology 1999 140 3334-3441. (doi:10.1210/endo.140.7.6861)

32 Nelson LE \& Bulun SE. Estrogen production and action. Journal of the American Academy of Dermatology 200145 116-124. (doi:10.1067/mjd. 2001.117432)

Received 5 May 2015

Revised version received 20 June 2015

Accepted 20 July 2015 